Portland State University

PDXScholar

Winter 2011

\title{
A Perspective on Preservation and Disaster Response Preparedness in Oregon Libraries
}

\author{
Alex Toth \\ Pacific University \\ Kristen Kern \\ Portland State University, kernk@pdx.edu
}

Follow this and additional works at: https://pdxscholar.library.pdx.edu/ulib_fac

Part of the Library and Information Science Commons

Let us know how access to this document benefits you.

\section{Citation Details}

Kern, Kristen and Alex Toth. "A Perspective on Preservation and Disaster Response Preparedness in Oregon Libraries.” OLA Quarterly. Vol. 17, no. 4 (Winter 2011): 8-12.

This Article is brought to you for free and open access. It has been accepted for inclusion in Library Faculty Publications and Presentations by an authorized administrator of PDXScholar. Please contact us if we can make this document more accessible: pdxscholar@pdx.edu. 


\section{A Perspective on Preservation and Disaster Response Preparedness in Oregon Libraries}

by Kristen Kern, MLS, MA

kernk@pdx.edu

Fine and Performing Arts Librarian, Portland State University Library

and

Alex Toth, MLS, CA

tothalex@pacificu.edu

Professor Emeritus,

Pacific University

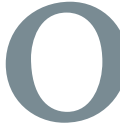

regon libraries share a unifying interest in the preservation of their collections. This interest is based on a common desire to be good stewards of the developing collections with which they have been entrusted. Preservation in this sense can encompass as many different strategies as there are libraries and range from formulating comprehensive disaster response plans to ongoing efforts to insure access to print and electronic resources.

The litany of natural disasters that have affected Oregon over the years is extensive and we are quite sure that everyone can recall several such events. Given the geographical diversity of our state, some of these events have directly affected our library structures and collections to greater (or lesser) extents. The potential distress of a disaster can, and often does, serve as a powerful motivator to action. However, it seems contrary to human nature to dwell for an extended period on calamities that can befall oneself, one's library, or one's collection. Because of this, imperatives to action can easily be displaced by the press of everyday activities, with the result that preservation and disaster preparedness often default to the bromide, "I'll get to it someday ..." One method that has proven to be effective as a way of following through on preservation and disaster preparedness activities is collective action by the formation of a group of individuals that have the responsibility for or a desire to preserve library materials in any number of circumstances. Such an approach serves the purpose of keeping and making the most of the collective energy of the group and the naturally collegial and collaborative orientation of libraries. Such an approach also serves as a subtle ongoing reminder to all involved of the consequences of a failure to follow through on preservation and disaster response preparedness activities.

In this article, we will examine one collaborative Oregon preservation effort that we believe is both enlightening and instructive for the example that it provides and for the direction that similar efforts may take in the future. The initiative that we have chosen to examine is that of the Disaster Recovery Group (DiRG) established by the Portland Area Library System (PORTALS). PORTALS was a library consortium founded in 1993 to meet the research and educational needs of libraries in the greater Portland area through cooperative and creative access to information resources and services. What made the consortium somewhat unique was its composition. Private and public universities, community colleges, public libraries, and an historical society in the states of Oregon and Washington were sustaining members of PORTALS. In the summer of 2000, The PORTALS Library Council, the consortium's governing body which consisted of the directors of member libraries and a historical society, sought out possible cooperative activities to undertake. Among those put forward was that of disaster response training. Recognizing that disasters could affect any and all participating institutions and that preparation to mitigate such events was in the interests of all members, the Council agreed that some form of disaster response planning and management would be mutually beneficial for PORTALS members.

Previous to this development were a number of efforts that focused attention on and created an interest in disaster response preparation and the preservation of library materials. Notable among these was a 1995 survey of preservation efforts in Oregon libraries. The survey was conducted by the OLA Special Committee on Preservation and published on behalf of the Committee by Normandy Helmer, Preservation and Binding Department Head at the University of Oregon Library in the Summer, 1997 issue of the OLA Quarterly. The article was titled, "The State of Oregon Preservation in 1995." 
The survey was divided into four parts, with one section devoted to "interest in preservation development." The article noted that "Oregon does not have a history of successful preservation networking and has had no experience in cooperative preservation efforts," however, "In Oregon, library consortia such as PORTALS and Orbis have the potential for fostering cooperative preservation." With regard to OLA's role, the Committee on Preservation suggested ".. the creation of a round table to facilitate the coordinated effort to develop statewide preservation activity, and the advocacy of OLA among state stakeholders, such as the Heritage Commission and members of the library consortia Orbis and PORTALS."

The same issue of the Quarterly also featured an article by Lawrence Landis, Acting Archivist, Oregon State University, titled "'Disaster Preparedness," in which he noted that, "Disaster preparedness is an essential part of the operation of a library or archives ..."

Another development which contributed to enhancing an awareness of the need for preservation activities and disaster preparedness in Oregon libraries was a 1998 meeting facilitated by the Regional Alliance for Preservation that sought to address the lack of preservation infrastructure and services in the Pacific Northwest. In that same year the Orbis Preservation Taskforce organized a meeting at Reed College, in Portland, to discuss local preservation needs, issues and ideas. In 1999, Orbis established a standing Preservation Committee which organized a Pacific Northwest preservation stakeholders meeting, held in Seattle, titled "Swimming Upstream."

The synergy created by the previously mentioned preservation activities led the PORTALS Executive Director to convene an August, 2000, meeting of an ad hoc preservation group of representatives from several PORTALS institutions. First on the agenda for the August meeting was a discussion of what disaster response planning encompassed. It was agreed that preservation needed to be part of comprehensive disaster response planning and that preservation efforts needed to be systematic and ongoing within institutions. At a subsequent meeting, the ad hoc group chose the name Disaster Response Group (DiRG) as its name and invited all PORTALS institutions to participate in its meetings.

Over the course of several meetings, DiRG developed a disaster response plan template with a general outline that could be customized for each participating library. The template would include common background information, local and regional preservation experts and facilities resources available for libraries, and a list of emergency response supplies. Much of the background information utilized to establish DiRG was adapted from similar California efforts: the San Diego/Imperial County Libraries Disaster Response Network (SILDRN) and the Inland Empire Libraries Disaster Response Network (IELDRN). DiRG recognized training as a critical need in order to provide disaster preparedness knowledge for PORTALS members and initiate library disaster response planning. They proposed a two-day workshop focusing on both institutional and inter-institutional disaster response planning. In addition, they determined to establish a mutual aid agreement, following IELDRN's model. This would require the commitment of each Council member to provide for a corps of trained workers, available on a volunteer basis to assist another library in the event of a disaster.

To accomplish these goals, the members of DiRG drafted a mutual aid agreement and brought it to the PORTALS Library Council for its review and approval. The Council members not only approved the draft for implementation, but agreed to place the mutual aid requirement in the PORTALS bylaws, rather than include it as an addendum. The 
bylaws stated that each PORTALS member will "maintain a current disaster preparedness plan and participate in mutual recovery aid when needed." The Council also accepted the proposal that DiRG facilitate emergency response preparation, promote emergency response awareness, and coordinate emergency response training for member libraries.

The Council funded a disaster response training in late fall, 2000, at which AMIGOS Library Services presented a two-day workshop that covered the basics of disaster preparedness and recovery. The first day's session was held at Portland Community College's Sylvania campus and focused on the following: what constitutes a disaster, disaster prevention, setting priorities, and creating a disaster plan. On the second day, in an empty industrial building which is now Linfield College's Jereld R. Nicholson Library, attendees participated in hands-on training recovering water damaged material from a simulated disaster. The experience of salvaging various media drenched in water enlightened participants to the real challenges involved in responding to a library emergency. A follow-up training for disaster management took place in the spring of 2001. Julie A. Page, then the Preservation Librarian at the University of California, San Diego, organized and facilitated a session entitled, "Exercising Your Disaster Plans," that provided an overview of disaster planning and described a disaster response exercise, implemented on her campus.

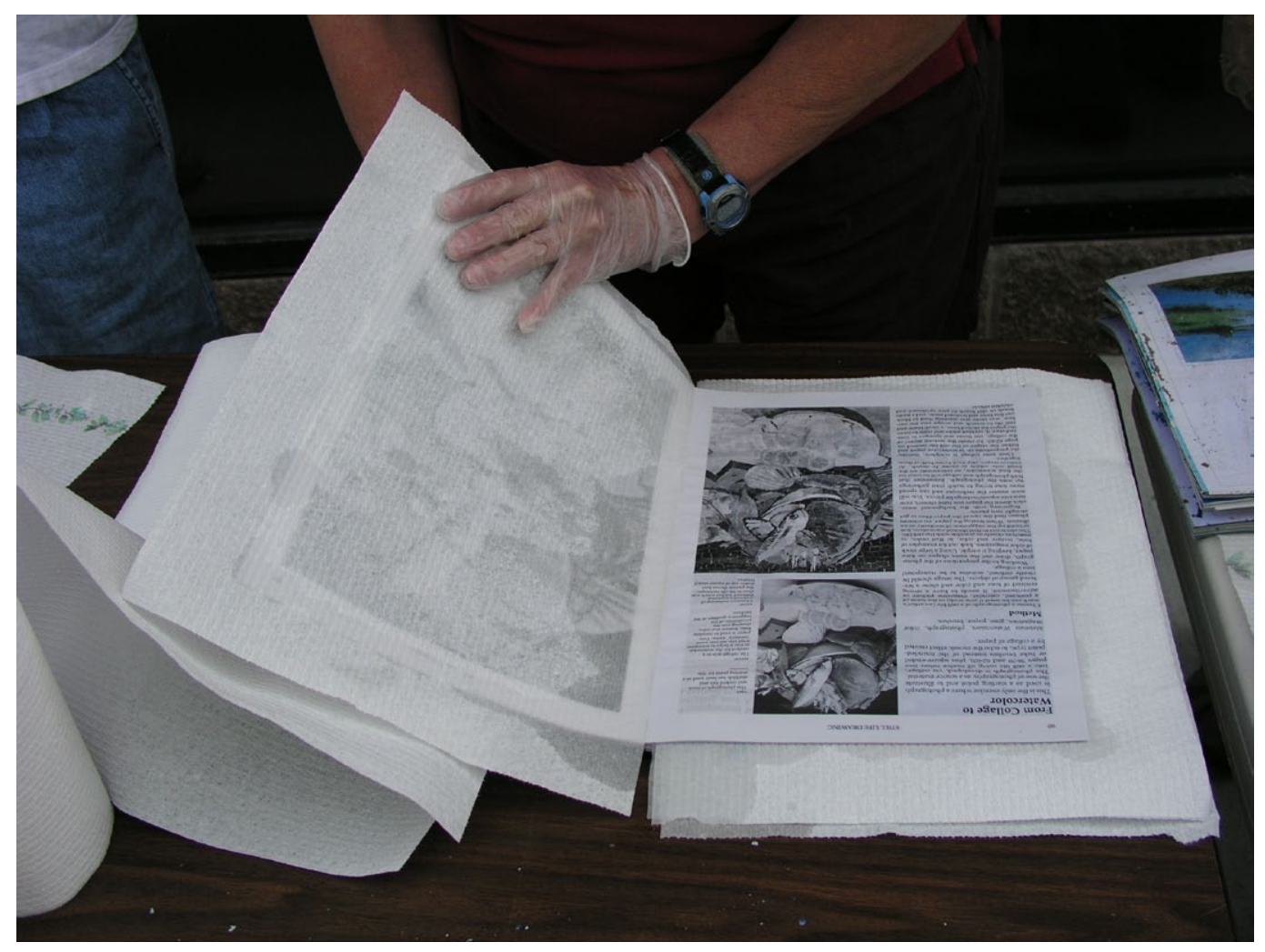

Learning the ropes in damage repair. 
To facilitate the development of disaster recovery plans for individual institutional members, minutes from DiRG meetings, a template disaster response plan, and disaster recovery information links were placed on the PORTALS Web site. One of the aims of DiRG's emergency preparedness effort was to develop a list of local resources that could be called upon for assistance in the event of an emergency. In the fall of 2001, an important step toward this goal occurred when a letter of understanding between PORTALS and a local cold storage company was drafted for the purpose of providing for interim storage space for water damaged materials.

Additional disaster response and preservation trainings were organized by DiRG under the auspices of PORTALS and made available to the Library community. These included:

Assessing Vulnerability and Identifying Risks, presented in October 2004 by Julie Page and Michael Smith of the Conservation Center for Art and Historic Artifacts at the Multnomah County Library, and

Emergency Preparedness Response and Recovery and Care and Handling of Collection Materials, presented in December of 2004 by Shelby Sanett of the AMIGOS library consortium.

While PORTALS membership was composed of a variety of institutions, it drew largely on the libraries of public and private universities. The need for such a formal organization diminished with the ongoing development of the Orbis consortium for academic libraries which had originated in 1997 with the development of a shared union catalog. Orbis joined with Washington academic libraries in the Cascade Alliance in 2002 to form the OrbisCascade Alliance. PORTALS was dissolved as an organization in 2007. Even though the PORTALS formal organization ceased, two of its important aspects continued, one of which was DiRG. The members of DiRG continued to meet informally and continued to promote disaster response and recovery planning and preservation activities. During this period several DiRG members were selected to attend the year-long Pacific Northwest Preservation Management Institute at the University of Washington. A DiRG member became a Western States and Territories Preservation Assistance Service (WESTPAS) trainer and another DiRG participant was successful in obtaining grant funds to organize and offer a Portland area workshop for first responders to disasters related to libraries and cultural heritage institutions.

DiRG continued as an informal interest group until 2008 when, on behalf of its members, DiRG co-chairs Kris Kern from Portland State University Library and Alex Toth from Pacific University Library successfully petitioned the Oregon Library Association for the creation of a Library Preservation Round Table. The Round Table identified its charge in part as facilitating communication among OLA members from all types of libraries, regarding the importance of the preservation of library materials, and increasing general awareness of preservation activities in libraries. The Library Preservation Round Table's ongoing involvement in the issue of disaster response and preservation has taken several forms. In 2008, a May Day Disaster Response Workshop was organized by Shawna Gandy of the Oregon Historical Society. That same year, the Round Table edited the Winter issue of OLA Quarterly, focusing on disaster preparedness in Oregon libraries. In both 2009 and 2010 the Round Table participated in poster sessions held in conjunction with the Oregon Library Association's Annual Meeting. 
One of the most significant contributions the Preservation Round Table has made is its position as a contributing member on the Steering Committee of the Connecting to Collections grant from the Institute for Museum and Library Services and administered by the Oregon Museums Association. The grant provided for a preservation needs survey among Oregon's libraries and cultural heritage institutions. This was in part a follow-up to the national Heritage Health Survey and sought to identify the needs and ways of addressing them.

In many ways, the DiRG and Preservation Roundtable "grass roots" efforts are typical of those in the Oregon library community. A need or opportunity is identified, and people are brought together by their mutual interests. As demonstrated in the case of DiRG and the LPRT, results take time to develop, and the process is ongoing. This development over time allows an opportunity for greater participation and a more solidified grounding for the preservation and disaster planning initiatives. In the case of DiRG, by working collaboratively with institutional support from libraries and consortia, as well as personal commitment, opportunities for improving the state of disaster readiness and preservation activities in Oregon libraries were enhanced. There is an expectation that, under the auspices of the Library Preservation Round Table, such efforts will continue well into the future. 4 海

\section{References}

Library Preservation Round Table, 2011, http://www.olaweb.org/mc/page.do?sitePageId=63278

Landis, Lawrence, "Disaster Preparedness," OLA Quarterly 3, no. 2 (1997): 6-7.

Helmer, Normandy, "The State of Oregon Preservation in 1995,"

OLA Quarterly 3, no. 2(1997): 2-5.

"Emergency and Disaster Preparedness and Response" [Special Issue], OLA Quarterly 14, no. 4, 2008. 